\title{
Employee Engagement Model: A Study Among Millennials
}

\author{
Ridwan Firdinata ${ }^{1}$, Hendriyani $^{2}$ \\ Graduate Program of Communication, Faculty of Social and Political Sciences, \\ Universitas Indonesia, Jakarta, Indonesia ${ }^{1}$ \\ Department of Communication, Faculty of Social and Political Sciences, \\ Universitas Indonesia, Jakarta, Indonesia ${ }^{2}$ \\ \{Hendriyani.sos@ui.ac.id²\}
}

\begin{abstract}
Employee Engagement is about uniting every resource (physical and psychological) of employee with the vision and mission of their organization. Study about employee engagement has become a very popular and important concept in organization and business studies. However, the employee engagement among millennial employee is lower than the previous generation. Using Structural Equation Modeling (SEM) as a tool to analyze the data, this research aims to confirm a model of factors than influencing employee engagement, that is the work itself, working environment, leadership, opportunity for personal growth, and opportunity to contribute. This research collecting data by using survey to 400 employees, across 15 Cities in Indonesia. The result of PLS SEM shows that work environment as the strongest driver factor of employee engagement. In second position is work itself which influence employee engagement. Opportunity contribute and leadership do not have significant direct influence to employee engagement. However, leadership has indirect influence to employee engagement through working environment, opportunity to contribute and opportunity to growth. This study combines determinants of employee engagement in framework that can be used by companies to identify factors that can engage and retain employees for organizational purpose. Model of employee engagement in this research is well suited for use in formal private sector in Indonesia. Further empirical study on multi generations and multi companies should be undertaken to ascertain the suitable model.
\end{abstract}

Keywords: Employee engagement; Millennial Generation; Structural Equation Modeling

\section{Introduction}

Employee engagement has become interesting discussion topics among Human Resource (HR) practitioners, consultants and also researchers. The essence of employee engagement is way to connecting hand, head, and hearts of the employee with the vision and the mission of their organization [1]. Talking about engagement is not only about working hard, not only about the vigor with which people work, not only their high levels of involvement, but it is about putting ourselves - our real selves - into the work [2]. In most cases, the term of 
employee engagement defined when employee is taken to mean some or all of "involvement, commitment, passion, enthusiasm, focused eff ort, and energy" into their organization [3]. The concept of engagement become very important because it will make the employee act in ways to achieve the objectives of both the organization and themselves [4]. Other things make this concept important because positive employee engagement results in increased quality and productivity and help to improve the image and credibility of the organization, increase customer satisfaction, and also reduce employee turn-over [5]. Level of employee engagement is very low. AON's [6] survey shows that only $27 \%$ of global employee are highly engaged and $14 \%$ are actively disengaged. Other survey conducted by WeSpire [7] tell us that $62 \%$ employee in this world are actively looking for a new job. An extreme result shows by TINYpulse [8] which talking about $43 \%$ employee around the world wanted to leave their companies.

Nowadays, HR practitioner are facing a new threat for employee engagement. new threat from new generation called millennials generation. This generation are employee whose born in between 1980 until 2002 [9]. There is so many unique characteristics about this new generations but most of them is in negative sounds. Millennials generations become the new threat because this generations will be dominating labor market on 2020 . PricewaterhouseCoopers [10] predicting that more than $50 \%$ of global employee will be fulfilled by millennials generation. In Indonesia, according to Badan Pusat Statistik (BPS) on 2020 population of millennials generation around 83 Million [11]. Threat from millennials generation are coming because their unique characteristics that must be concerned by companies. They will leave the companies soon when what they wanted are not fulfilled [10]. Survey conducted by Deloitte [12] shows that $44 \%$ millennials generations willing to leave the companies within two years. In the other word, they are actively disengaged.

Many factors are driving level of employee engagement. Armstrong says that there are five factors can be driving level of engagement such as; leadership styles, work it-self, work environment, opportunity to contribute and opportunity for personal growth [4]. When the companies improving those factors quality, the engagement level also can be increasing. This paper aim to look the model constructed between driving factors - leadership styles, work itself, work environment, opportunity to contribute and opportunity for personal growth - and employee engagement to be used by researchers and practitioner to reduce the gaps between research literature and practices, especially in the employee engagement context.

\section{Method}

Quantitative descriptive research with survey method are applied for this paper. This paper use questioner with Likert scale 1-6 as research tool. Concept operationalization are breakdown in Table 1. Population of this research was 2.048 millennials employees from private company in Indonesia. Using sample calculator from www.raosoft.com, this research has 400 samples with confidence level $95.5 \%$ and margin of error $4.5 \%$. Hypothesis of this research is "There is a model constructed by relationship between variables." To confirm the hypothesis, this research using partial least squares - structural equation modeling (PLSSEM). Data collected from questioner are proceed using SPSS v23.0 to get the validity and reliability. Then using SmartPLS 3.0 to looking for the model constructed by variable. 


\section{Result and Discussion}

This paper using six steps to assessing the structural model in PLS-SEM: (1) assessing evaluation of measurement model; (2) assessing the level of the R2 values; (3) assessing the significance of the path coefficients; (4) assessing the f2 effect size; (5) assessing the predictive relevance (Q2); (6) assessing the Model predictive capability.

Step 1. This paper doing evaluation of measurement model to confirm that estimated model (figure 1) is suitable to get assess with PLS-SEM.

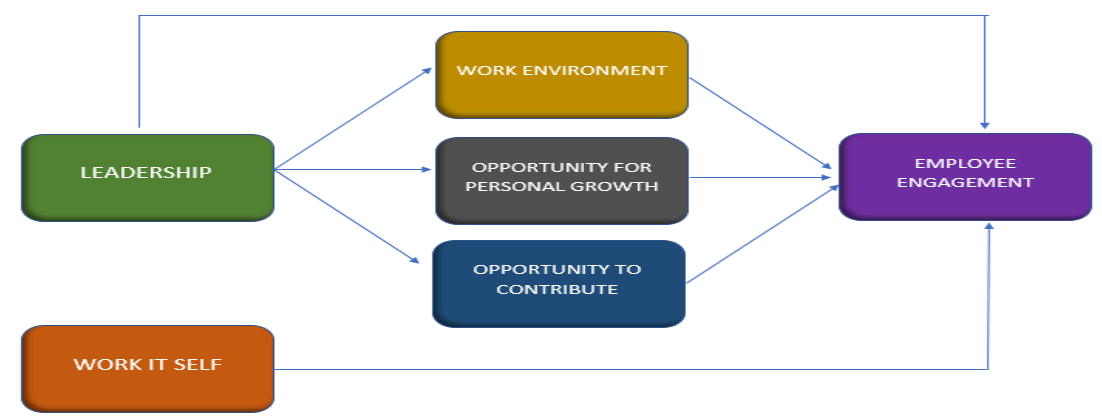

Fig. 1. Estimated Model

The evaluation conduct by evaluating the value of cronbach's alpha, rho A, composite reliability, and average variance extracted (AVE). This Table 1 shows the evaluation result.

Table 1. Evaluation of Measurement Model

\begin{tabular}{lcccc}
\hline \multicolumn{1}{c}{ Construct } & $\begin{array}{c}\text { Cronbach's } \\
\text { Alpha (SmartPLS) }\end{array}$ & rho_A & Composite Reliability & AVE \\
\hline Employee Engagement (EE) & 0.866 & 0.872 & 0.891 & 0.407 \\
Work It-Self (WS) & 0.843 & 0.858 & 0.885 & 0.566 \\
Working Environment (WE) & 0.82 & 0.849 & 0.862 & 0.418 \\
Leadership (L) & 0.916 & 0.917 & 0.935 & 0.7 \\
Opportunity for Personal Growth (OPG) & 0.898 & 0.903 & 0.923 & 0.668 \\
Opportunity to Contribute (OC) & 0.806 & 0.823 & 0.872 & 0.630 \\
\hline
\end{tabular}

In Table 1 , the result shows that every variable has value above 0.7 . Whereas the AVE value of employee engagement and working environment are below 0.7 , it still tolerable because the value of composite reliability of them are more than 0.7 .

Step 2. Assessing coefficient of determinant $\left(\mathrm{R}^{2}\right)$ value from each variable. This step conduct to predict the accuracy and is calculated as the squared correlation between a specific endogenous construct's actual and predicted values [13].

Table 2. Result of Coefficient of Determinant

\begin{tabular}{lcc}
\hline \multicolumn{1}{c}{ Endogenous Construct } & $\mathbf{R}^{\mathbf{2}}$ & Category \\
\hline Employee Engagement (EE) & 0.783 & Substantial \\
Working Environment (WE) & 0.470 & Moderate \\
Opportunity for Personal Growth (OPG) & 0.573 & Moderate \\
Opportunity to Contribute (OC) & 0.472 & Moderate \\
\hline
\end{tabular}


Value of $\mathrm{R}^{2}$ divided into three categories. Substantial when the $\mathrm{R}^{2}>0.75$, moderate when $0.25<\mathrm{R}^{2}<0.75$, and weak when $\mathrm{R}^{2}<0.25$. Substantial and moderate means the exogenous construct has correlation to endogenous construct.

Step 3. Assessing path coefficient and t-value. This assessment to look the path significance between exogenous and endogenous. Path coefficient value $>0.20$ is significant, and $<0.10$ is not significant. For t-value $\geq 1.96$ or $\geq-1.96$ is significant.

Table 3. Result of Path Coefficient and t-value

\begin{tabular}{lccc}
\hline \multicolumn{1}{c}{ Path } & $\begin{array}{c}\text { Path } \\
\text { Coefficient }\end{array}$ & t-value & $\begin{array}{c}\text { Significant/ not } \\
\text { significant }\end{array}$ \\
\hline Leadership $\rightarrow$ Employee Engagement & -0.090 & 1.736 & Not significant \\
Leadership $\rightarrow$ Working Environment & 0.685 & 17.720 & Significant \\
Leadership $\rightarrow$ Opportunity for personal growth & 0.757 & 25.513 & Significant \\
Leadership $\rightarrow$ Opportunity to Contribute & 0.687 & 15.955 & Significant \\
Work it-self $\rightarrow$ Employee Engagement & 0.439 & 7.565 & Significant \\
Working Environment $\rightarrow$ Employee & 0.474 & 7.728 & Significant \\
$\begin{array}{l}\text { Engagement } \\
\text { Opportunity for Personal Growth } \rightarrow \text { Employee }\end{array}$ & 0.157 & 3.211 & Significant \\
$\begin{array}{l}\text { Engagement } \\
\text { Opportunity to Contribute } \rightarrow \text { Employee }\end{array}$ & 0.007 & 0.143 & Not significant \\
Engagement & & & \\
\hline
\end{tabular}

The result of path coefficient and t-value shows that most of construct path are significant. But, path between leadership to employee engagement, and path between opportunity to contribute to employee engagement are not significant.

Step 4. Assessing $\mathrm{f}^{2}$ effect size. The $\mathrm{f}^{2}$ effect size conduct to analyze the relevance of constructs in explaining selected endogenous latent constructs. More specifically, to analyze how much a predictor construct contributes to the $\mathrm{R}^{2}$ value of a target construct in the structural model [13]. There are three categories of $\mathrm{f}^{2}$ value, 0.02 to 0.15 is small effect, 0.15 to 0.35 is middle effect, and $>0.35$ is big effect.

Table 4. Result of $\mathrm{f}^{2}$ Effect Size

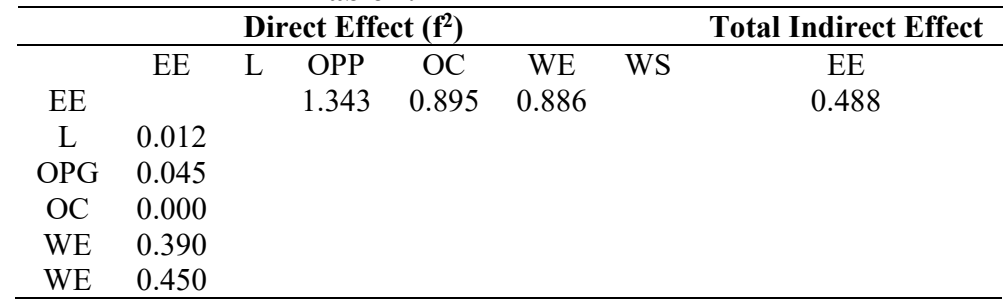

From the result, Leadership and opportunity to contribute has no direct effect to employee engagement. But leadership has middle in total indirect effect to employee engagement.

Step 5. Assessing predictive relevance $\left(Q^{2}\right) . Q^{2}$ is a measure of predictive relevance based on the blindfolding technique. Q2 values larger than zero for a certain reflective endogenous latent variable indicate the path model's predictive relevance for the particular construct. This paper use construct crossvalidated redundancy method to assessing $\mathrm{Q}^{2}$. 
Table 5. Result of $\mathrm{Q}^{2}$

\begin{tabular}{lccc}
\hline \multicolumn{1}{c}{ Endogenous construct } & SSO & SSE & $\mathbf{Q}^{\mathbf{2}}$ (=1-SSE/SSO) \\
\hline Employee Engagement (EE) & $4,800.000$ & $3,416.703$ & 0.288 \\
Opportunity for Personal Growth (OPG) & $2,400.000$ & $1,605.386$ & 0.331 \\
Opportunity to Contribute (OC) & $1,600.000$ & $1,170.002$ & 0.269 \\
Work Environment (WE) & $3,600.000$ & $2,970.570$ & 0.175 \\
\hline
\end{tabular}

Step 6. Assessing the model predictive capability by calculating $\mathrm{Q}^{2}$ based on $\mathrm{R}^{2}$.

$\mathrm{Q}^{2}=1-\left(1-\mathrm{R} 1^{2}\right)\left(1-\mathrm{R} 2^{2}\right) \ldots\left(1-\mathrm{Rm}^{2}\right)$

$\mathrm{Q}^{2}=1-(1-0.783)(1-0.470)(1-0.573)(1-0.472)$

$\mathrm{Q}^{2}=1-0.026$

$\mathrm{Q}^{2}=0.974$

The measurement of model predictive capability is $\mathrm{Q}^{2}$ must higher than 0 and less then 1 , or $0<\mathrm{Q}^{2}<1$. Based on calculation, $\mathrm{Q}^{2}$ fo $\mathrm{r}$ estimated model in this paper is $0<0.974<1$. That means this model are good enough the predictive capability.

Assessment by PLS-SEM has result that the estimated model has good predictive capability, even there is some path that not significant. Figure 2 shows the final model.

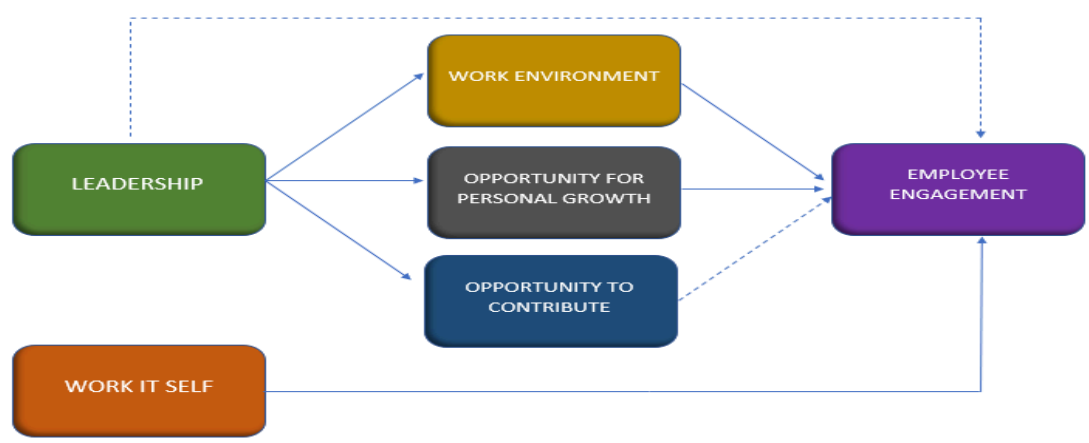

Fig.2. Final Model

Differences between estimated model and finale model can be seen at path of leadership to employee engagement and path of opportunity to contribute to employee engagement. According to result of model predictive capability is $0<\mathrm{Q}^{2}<1$, Hypothesis 1 - There is a model constructed by relationship between variable - is accepted.

Assessment result at path coefficient between leadership to employee engagement is 0.090 and t-value 1.736, this condition makes this direct path are not significant and not relevant. Direct effect value from leadership to employee engagement is 0.012 . It means leadership has no direct effect to employee engagement. But indirectly leadership has big effect to employee engagement with total indirect effect value is 0.448 . This result means the managers in the company unable to get the heart of millennials directly. Managers must have mediator construct to improve employee engagement level.

DelCampo, Haggerty, Haney, \& Knippel, says that managers have to change their leadership styles to improve engagement level at millennials generation [14]. The changing means to be more open-minded, giving autonomy, and trust to millennials. Hulett argued that to face millennials basically the managers have to change their mind about "seniority" [15]. It because millennials generation don't like concept of seniority and rigid structure. Hymowitz give tips for managers to face the millennials, they should keep in their mind that age is not the key of success, every employee has their own expertise and deserve to get appreciation 
[16]. Sujansky \& Reed says that company failure to improve level engagement of millennials commonly caused by the manager's attitude and behavior. Nowadays, managerial level filled by generation $\mathrm{X}$ and baby boomer [17]. Most of them cannot facing the truth that millennials are different.

Path coefficient between leadership to working environment is 0.685 with t-value 17.720 , this result makes the path is significant and relevant. The result of path coefficient between working environment to employee engagement is 0.474 and t-value is 7.728 . the value of direct effect form working environment to employee engagement is 0.39 . the value of direct effect form leadership to working environment is 0.886 . The value of specific indirect effect of leadership to employee engagement through working environment is 0.325 . This means that leadership has effect to employee engagement indirectly through working environment.

Topping argued that one of manager's responsibility is to make conducive, effective, and positive working environment for the employee, and efficient for the organization [18]. Armstrong says that positive working environment can be reach when the managers keep in their mind that every employee is independent [4]. It means every employee has their own needs, goals, attitude, and behavior. Flodspang give the indicators that managers have to concern to create positive working environment, there is physical indicators, psychological indicators, and welfare [19]. In case to face the millennials, DelCampo, Haggerty, Haney, \& Knippel giving tips that to embraced millennials the working environment must be create flexible, supportive, fair, and giving touch of high technology [14]. Based on result and theoretical it can be concluded that the managers in the organization sample is already create positive working environment.

Result of path coefficient between leadership and opportunity for personal growth is 0.757 and t-value 25.513. The value of direct effect from opportunity for personal growth to employee engagement is 0.045 . the value of direct effect from leadership to opportunity for personal growth is 1.343 . The value of specific indirect effect of leadership to employee engagement through opportunity for personal growth is 0.119 . It means leadership has effect to employee engagement indirectly through opportunity for personal growth.

The result shows that managers are already in the right way to engaged employee through employee opportunity for personal growth. Armstrong put learning for employee is kind of investment [4]. Every employee must be supported, and encouraged to increase their skills and competencies through coaching, training, and learning. Sujansky \& Reed argued that is five basic idea to give learning to millennials; keep it short, hands-on experiences, team-based learning, create visual experience, and make it real [17].

Path coefficient and t-value of leadership to opportunity to opportunity to contribute is really significant in 0.678 and 15.955 . But, the value of path coefficient and t-value from opportunity to contribute and employee engagement is only 0.007 and 0.143 , it means this path is not significant. Opportunity to contribute is also don't have effect to employee engagement as result value 0.000 . Leadership has big effect to opportunity to contribute, but leadership have very weak indirect effect to employee engagement through opportunity to contribute as result value 0.004 . This result means that managers have big power to employee voice, but that power are not be used in right way to improve employee engagement level.

Survey conducted by Deloitte shows that millennials are not interest to giving their voice for organizational goods [12]. PricewarerhouseCoopers says that phenomenon is happened because millennials is only thinking about their self-improvement, not about organization sustainability[10]. Sujansky \& Reed argued that there is one of managers duty to encourage millennials to talk about organization goods [17]. 
The path coefficient of work it-self to employee engagement is 0.439 and t-value 7.65. Direct effect of this path is 0.455 . This result means that the path between work it-self and employee engagement is significant, relevant, and have big effect. This result is in same track with many researches which says work it-self is can be driving employee engagement level in millennials generation [20][21]. Work it-self can be driving employee engagement lave if only the work has cool factor [17]. That factor can make millennials being pride working at the organization.

\section{Conclusion}

Result of this paper shows that there is model developed by relationship between construct; work it-self, leadership, working environment, opportunity to contribute, and opportunity for personal growth, to employee engagement in millennials generation. Whereas leadership has no direct effect to employee engagement, but leadership has big effect to employee engagement indirectly through working environment, opportunity to contribute, and opportunity to growth. According to the model, the biggest effect to employee engagement for millennials generation is work it-self and followed by working environment. The lowest effect is opportunity to contribute. This result can be used by Human Resource practitioners to improve employee engagement level especially millennial generation. This paper far from perfect and there are many limitations can be improved for next research. Author suggest to use mix method for next study to get more comprehensive result. We also suggest to get data from multi generation so the result can be more holistic for employee engagement.

\section{References}

[1] M.S. Rao, M.S. "Innovative tools and techniques to ensure effective employee engagement. Industrial and Commercial Training, Vol. 49, No. 3, pp.127-131, 2017.

[2] W.A. Kahn. The essence of engagement: lessons from the field. In S.L. Albrecht, Handbook of Employee Engagement Perspectives, Issues, Research \& Practice. Cheltenham: Edward Elgar, 2010.

[3] W.H. Macey, and B. Schneider, B. "The Meaning of Employee Engagement." Industrial and Organizational Psychology, No. 1, pp. 3-30, 2008.

[4] M. Armstrong. Armstrong's Handbook of Human Resource Management Practice $11^{\text {th }}$ Ed. London: Kogan Page, 2009.

[5] A. Gilley, J.W. Gilley, S. Quarto and P. Dixon. The Praeger Handbook of Human Resource Management. Westport: Preager, 2009

[6] Hewitt. 2018 Trends in Global Employee Engagement. Retrieved from www.aonhewitt.com

[7] WeSpire. State of Employee Engagement. Retrieved from http://www.wespire.com/wp-content/ uploads/2019/03/State-of-EmployeeEngagement-2019.pdf, 2019.

[8] Tinypulse. THE 2019 EMPLOYEE ENGAGEMENT REPORT: The End of Employee loyalty. Retrieved from https://www.tinypulse.com/hubfs/EE\%20Report\%202019.pdf, 2019.

[9] A. Tolbize. Generational differences in the workplace. Minnesota: University of Minnesota, 2008. 
[10] PricewaterhouseCoopers. Millennials at Work: Reshaping the workplace. London: PWC, 2011.

[11] Badan Pusat Statistik. Keadaan Ketenagakerjaan Indonesia Agustus 2017. Jakarta: BPS, 2017.

[12] Deloitte. The 2016 Deloitte Millennial Survey. London: Deloitte,2016.

[13] J.F. Hair, G.T.M. Hult, C.M. Ringle, \& M. Sarstedt. A Primer on Partial Lieast Squares Structural Equation Modeling (PLS-SEM). Los Angeles: Sage Publication, 2014.

[14] R.G. DelCampo, L.A. Haggerty, M.J. Haney \& L.A. Knippel. Managing the MultiGenerational Workforce from the GI Generation to the Millennials. Surrey: Gower, 2011.

[15] K.J. Hulett, K. J. "They are here to replace us: Recruiting and retaining Millennials." Journal of Financial Planning, No. 17, 2006.

[16] C. Hymowitz. "Managers find ways to get generations to close culture gaps." The Wall Street Journal. Retrieved from http://www.wsj.com/articles/SB118393605602060381, 2007.

[17] J.G. Sujansky and J.F. Reed, Keeping the Millennials: Why Companies Are Losing Billions in Turnover to This Generation and What to Do About It. New Jersey: Wiley, 2009.

[18] P.A. Topping. Managerial Leadership. NewYork: MacGraw-Hill, 2002.

[19] L.Foldspang, L., et al. Working environment and productivity: A register-based analysis of Nordic enterprises. Nordic Council of Ministers. Copenhagen: RosendahlsSchultz Grafisk, 2014.

[20] W.B. Schaufeli, W.B. What is engagement? In C. Truss, K. Alfes, R. Delbridge, A. Shantz, \& E. Soane (Eds.), Employee Engagement in Theory and Practice. London: Routledge, 2013.

[21] R.E. Smerek \& M. Peterson. "Examining Herzberg's Theory: Improving Job Satisfaction among Non-Academic Employees at a University. Research in Higher Education, Vol. 48, 2, 229-249, 2007. 